\title{
Empirical Legal Research: Fad, Feud or Fellowship?
}

\author{
Peter Mascini \& Wibo van Rossum*
}

\begin{abstract}
As co-editor, I dedicate this special issue to Wibo van Rossum, who sadly passed away during the making of it. Wibo initiated this special issue and, despite his grave illness, was determined to help accomplish it. The idea of editing this special issue originated from the annual conference of the Dutch Lam and Society Association (VSR) that we organised in Rotterdam in 2016 together with Roel Pieterman and Nick Huls. In 2017, with Hilke Grootelaar, me edited a special issue for the journal of the VSR, Recht der Werkelijkheid, entitled Recht als probleemoplossing? (The Law as Troubleshooter?). This indicates that I have collaborated with Wibo on different occasions, also during his illness. Doing so was always a great pleasure and Wibo has been an example to me in the dignified and resilient manner in which he carried on to doing the mork he loved so much, with passion until the end.
\end{abstract}

At the end of the last century, a movement emerged on the legal scholarship landscape in the United States that is often referred to as Empirical Legal Research (ELR). This breakthrough in the status quo within the research field of law has since aroused debate and raised questions. Some of these questions arise from the need to better understand this new movement. How can the rise of ELR be explained? What are its main characteristics? Who is part of it? Does this movement also spread outside the US? If so, where and how? The rise of ELR also leads to reflection on the existing research field of the law. How does ELR relate to legal scholarship, the Law and Society (L\&S) movement and (New) Legal Realism? What does the emergence of the ELR movement imply for the established institutional and power relations within the research field? Since, at least at the beginning, ELR was thought to focus more on quantitative research methods and to take a less critical and more instrumental stance towards the study of the law than already existing empirical research traditions, it also gives cause for reflection on more fundamental questions about the study of the law. The first question is epistemological: how do empirical legal research and legal scholarship compare? Next is the ontological question of how law and empiricism relate to each other. In other words, the rise of ELR elicits reflection in various

Erasmus University Rotterdam, Erasmus School of Law. Corresponding author: Peter Mascini, Sanders building, 7 West, P.O. Box 1738, 3000 DR, Rotterdam, The Netherlands, pmascini@gmail.com. Thanks to Rob Schwitters for his valuable comments on the draft of this text. ways. The answer to these questions, about ELR itself, about the positioning of ELR within the research field and about the relationship between law and empiricism and the investigation thereof, can be sought in various ways, has not yet been found in many respects or is controversial. In the four contributions to this special issue, three of the more fundamental questions are addressed that are prompted by the emergence of ELR.

The first question concerns the relationship between law and empiricism. One way of characterising this relationship is the well-known dictum 'law in books and law in action.' The conception of 'law in action' is associated with Legal Realism, which examines the role of law, not just as it exists in the statutes and cases, but as it is actually applied in society. The law may contain ideals to strive for, but research on the social practice of law has made clear that the law is fooling itself, because it contains a lot of mechanisms that make sure those ideals remain ideals. ${ }^{1}$ Danielle Chevalier shows in her contribution to this special issue that the prevailing distinction between 'law in books and law in action' does not do justice to the relationship between the way in which the law is formalised, perceived and lived. Though the mutual constitution between law and practice is nowadays commonly professed, the reflex remains to use law in books as starting point. It is argued, however, in this article that law has a storyline that commences before its institutional formalisation. Law as 'a continuous process of becoming' encompasses both law in books and law in action, and law in action encompasses timelines both before and after the formal coming about of law. To fully understand law, it is necessary to understand the entire storyline of law. To illustrate this, an ethnographic case study of a local by-law regulating an ethnic diverse public space of everyday life is expanded upon. The case study is used to demonstrate the dynamics in which law comes about and how these dynamics continue for law in action after law has made the books. This particular case study exemplifies how law is one of many truths in the context in which it operates and how formalised law is, above all, reflective of the power constellations that have brought it forth.

There is another manner in which the relationship between law and empiricism can be conceived. On a more abstract level, it can be reformulated as that between law and its environment. This latter relation-

1. D.E. Ingersoll, 'American Legal Realism and Sociological Jurisprudence: The Methodological Roots of a Science of Law', 17 Journal of the History of the Behavioral Sciences (1981), at 491. 
ship is central to the so-called system theory. According to this theory, a process of functional differentiation brings forth specialised subsystems (such as law, politics, science, religion) that fulfil an exclusive function that none of the other subsystems can take over. Moreover, the subsystems are self-regulating: from their own survival strategy they derive which signals from the environment they respond to. ${ }^{2}$ According to Luhmann, systems are cognitively open and operationally closed. ${ }^{3}$ This means that they are sensitive to and respond to signals from the environment but that they interpret them from their own operational criteria, i.e., the way in which the system is organised. For a new signal, for example an empirical finding, to reach the legal system, it must be recognised as legally relevant by the law. The law itself determines which actions are considered legal acts (norms) and which mere factual actions (facts).Whereas other-reference ensures the system's cognitive openness towards its environment, self-reference ensures its normative closure.

How are empirical observations entered into the operational logic of the law? Case files, for example, play an important role here. '[T]he case file authorizes and authenticates, ascribes actions to actors and thereby enrols them in the legal case, and it references events and persons in such a way as to attribute legal-factual status to them so that they, too, are enrolled in the workings of the legal case.... Approached as such, the legal case file can further understanding of how "law" establishes itself in relation to a world it references as "outside" but that it, by so referencing, can only deal with as a world enrolled in law, that is, as a legally domesticated world.' ${ }^{4}$ Van Gestel en Van Lochem's contribution to this special issue illustrates that also the process of drafting regulatory policies can help elucidate how a border between law and empiricism is enacted. Inherent to all regulatory policymaking is that a 'jump' has to be made from empirical facts (i.e. other referencing) to normative recommendations of what the law should regulate (i.e. self-referencing). For example, the observations that there are too few organ donors in the Netherlands and that the voluntary registration system is not working has to be translated into normative recommendations of what the law should regulate (e.g. we need to change the default rule so that everybody in principle becomes an organ donor unless one opts out). The authors analyse how this translation process takes place and whether it makes a difference if the empirical research on which legislative drafts are built concerns predominantly quantitative or qualitative research. By using the lens of the proportionality principle - which requires that proposals for new legislation are suited to

2. N. Huls, Actie en reactie: Een inleiding in de rechtssociologie (Action and Reaction: An introduction in the Sociology of Law), (2009) Den Haag: Boom Juridische uitgevers, at 70-74.

3. N. Luhmann, Das recht der gesellschaft (The Law of Society), (1993) Verlag: Suhrkamp.

4. I. Van Oorschot and W. Schinkel, 'The Legal Case File as Border Object: On Self-Reference and Other-Reference in Criminal Law', 42 Journal of Law and Society 4 (2015), at 501. accomplish the aims of the legislature, do not require more intrusive measures than strictly necessary to reach these aims, and will not produce excessive burdens for particular addressees of the rules - in a case study of each type, they conclude that the manner in which empirical data and scientific evidence are used by legislative drafters to justify normative choices in the design of new laws fail to meet the proportionality test.

As noted, the rise of ELR with its alleged focus on quantitative research methods and addressing practical policy issues apolitically gives reason to reflect on the way in which law and empiricism relate to each other. The first two articles from this special issue make a valuable contribution to a better understanding of this relationship. Chevalier shows that the mutual influence of 'law in books and law in action' is a dynamic process where the formalisation of legislation is neither the beginning nor the end. Van Gestel and Van Lochem show that the way in which legislative drafters pick up signals from the environment and convert them into legal rationality usually does not meet the terms against which their own operational actions are evaluated.

The second question addressed in this special issue concerns the relationship between a legal and an empirical study of the law. Does empirical legal research gain importance? There are several reasons to assume that it indeed thrives.

First, legal scholarship may contribute to the growth of empirical legal research. It took a long time for legal scholarship to acquire a respectable and self-evident position within the academic community. It was only after it had succeeded in achieving this status that scope for empirical legal research emerged in law faculties. In combination with the emergence of the social sciences as discrete fields of study and the development of related methodologies, the maturation of law as an academic discipline seems to have been a driver for empirical legal research. ${ }^{5}$ The fact that leading scholars in legal faculties plead for more empirical research may also have contributed to empirical legal research as status enhancing and therefore rendering law faculties eager to take the lead in international and interdisciplinary research.

Second, legal practice may contribute to the growth of empirical legal research. During their education and onthe-job training, lawyers are confronted with research that teaches them more about their own functioning or provides insight into problems and developments that they face in their daily work. Moreover, they are confronted with litigants and expert witnesses who provide empirical data in court cases that judges must be able to judge. The environment also expects them to have the capacity to properly evaluate these empirical data. These concerns have led to the need and desire for empirical research that judges can draw from when making their decisions. ${ }^{6}$ Incidentally, a caveat must be

5. M. Heise, 'The Past, Present, and Future of Empirical Legal Scholarship: Judicial Decision Making and the New Empiricism', University of Illinois Law Review 4 (2002).

6. Ibid., at 832 . 
entered in relation to this factor. Although research shows that lawyers occasionally learn about empirical research, consider themselves capable of understanding it and understand its importance, they still make little use of it in practice. $^{7}$ Insofar as the legal practice is responsible for the growth of empirical legal research, nonetheless, the increasing availability of data, for example, as a result of the digitisation of the judiciary obviously also contributes to it. ${ }^{8}$

Third, law and economics may have boosted empirical legal research. Since the 1960 s, economic theory has been successfully applied to the law. The predominant assumption of law and economics was that individuals make rational choices in response to incentives that emanate from legal instruments. From this assumption theoretical predictions are derived and recommendations made for the optimisation of legal instruments. This assumption of the rational actor has been problematised for some decades now by behavioral scientists who study the law empirically. ${ }^{9}$ These behavioral scientists are dominated by lawyer-economists and psychologists who mainly do large-scale quantitative and experimental research. Their research has demonstrated that the assumption of the rational actor is problematic since the will power, rationality and egoism of actors in their responses to legal instruments are bounded. The dissatisfaction about the assumption of the rational actor in law and economics thus seems to have played an independent role in the growth of empirical legal research. ${ }^{10}$ Have these factors actually led to a demonstrable growth of empirical legal research? Several studies to which Van Dijck, Sverdlov and Buck refer in their contribution to this special issue show that there has indeed been an increase in empirical legal research in the US. The question of whether this growth also applies to Europe has not yet been systematically investigated, according to these researchers. They have taken on the task of finding out. They make a distinction between legal and empirical legal research on the basis of the research method and the use of data that are reported in the articles that they rely on in their study. Based on a content analysis of 78 journals, they establish that there has not been an increase in empirical research in Europe between 2008 and 2017. They address the potential reasons for this absence of growth and discuss how its obstacles can be alleviated. Hereby they mention the availability of data, training and the formulation of questions that are relevant to the legal practice. Their findings subsequently raise the question whether the

7. N. Elbers, M. Malsch, P. Van Der Laan, A.J. Akkermans \& C. Bijleveld, 'Empirisch-juridisch onderzoek in Nederland: Bespiegelingen over de stand van zaken in de rechtswetenschap, het juridisch onderwijs en de rechtspraktijk' ('Empirical-Legal Research in the Netherlands: Reflections about the State of the Art in Jurisprudence, Legal Education, and the Legal Practice'), 39 Recht Der Werkelijkheid 1 (2018).

8. C.L. Boyd, 'In Defense of Empirical Legal Studies', 63 Buffalo Law Review (2015), at 371-72.

9. P. Mascini, 'Responses of Law and Economics to the Threat of Its Initial Success', Law and Method (2018), doi:10.5553/REM/.000032.

10. R. Lempert, 'Growing Up in Law and Society: The Pulls of Policy and Methods', 9 Annual Review of Law and Social Science (2013), at 13. presumed drivers of empirical legal research mentioned earlier may also be limited to the US.

The last question addressed in this special issue concerns the way in which the ELR movement and other research traditions dealing with the empirical study of the law substantively relate to each other. In this discussion it is rightly pointed out that the law was studied empirically long before ELR emerged. That research took place around the beginning of the twentieth century, mainly in the US, under the heading of Legal Realism. Today it is being continued under the heading of New Legal Realism ${ }^{11}$ or European New Legal Realism. ${ }^{12}$ Subsequently, the L\&S movement was established in the early 1960s. In some respects the ELR movement is considered a reaction to the $L \& S$ movement. ELR caught the attention of lawyers because the new movement seemed to promise research on legally relevant facts without too much social theory, and without the usual criticism of the deficiencies of law. These last characterisations of 'focus on social theory' and 'critical about the deficiencies of law' are typical for much of the L\&S movement. ${ }^{13}$ The L\&S movement with its broad interest in immigration law, development in crime, gender issues, the North-South divide and global development, social and economic inequality, the functioning of the legal profession and of courts, inclusion and exclusion of citizens through law etc., has conducted empirical research for many decades. But it has done so almost always with an eye on developing theoretical positions in social theory and speaking critically to power with the aim of furthering justice for marginalised and suppressed individuals and minorities. ELR presented itself as freed from the ballast of social theory and critique. It claims to pose more pragmatic questions than L\&S research, with more focus on policy and practical relevance and less focus on theory. ${ }^{14}$ Moreover, methodologically, ELR appears to be less pluriform than L\&S research. Certainly in the US and at the first European Conference on Empirical Legal Research, the emphasis was on quantitative research. ${ }^{15} \mathrm{Or}$ so it is perceived. These perceptions contain elements that feed tensions in the L\&S movement that may feel it is overhauled, in the ELR movement that may feel wrongly shelved as being a-theoretical, and in legal scholarship that may be afraid to miss the train to new legal methodologies and theories about law.

11. H. Dagan and R. Kreitner, 'The New Legal Realism and the Realist View of Law', 43 Law \& Social Inquiry 2 (2018).

12. J. v. Holtermann and M.R. Madsen, 'What Is Empirical in Empirical Studies of Law? A European New Legal Realist Conception', 39 Retfærd 4 (2016).

13. K. Van Aeken, 'Sociology of Law in Search of a Distinct Identity', 36 Recht Der Werkelijkheid 1 (2015)

14. G. Van Dijck, 'Naar een succesformule voor empirisch-juridisch onderzoek' ('Towards a Success Formula for Empirical-Legal Research'), 42 Justitiële Verkenningen 6 (2016), at 31 and D. Blocq and M Van Der Woude 'Empirisch-juridisch onderzoek' ('Empirical Legal Research'), 38 Recht Der Werkelijkheid 3 (2017), at 33-34.

15. T. George, 'An Empirical Study of Empirical Legal Scholarship: The Top Law Schools', 81 Indiana Law Journal (2006), at 141. 
In reality, the foregoing story is not black and white. In the first place because the two movements do not manifest themselves everywhere in the same way. For instance in Germany unlike in the US, empirical legal scholars may find themselves outsiders in relation to the legal community, as their work is not readily considered relevant for legal scholarship (Rechtswissenschaft), which is usually regarded as a normative enterprise. ${ }^{16}$ In the Netherlands, the Empirical Legal Scholarship initiative (ELSi) seems to be methodologically inclusive and, above all, opting for a pragmatic approach with a focus on promoting empirical legal research rather than instigating a fundamental reflection on the relationship between legal science and empirical legal research. ${ }^{17}$

Secondly, Van der Woude and Blocq show in their contribution to this issue that empirical research traditions are evolving. Their contribution to this special issue relates to the relationship between the ELR movement and the L\&S movement. The article departs from the observation that the ELR movement, understood as an initiative that emerged in American law schools in the early 2000s, has been quite successful in generating more attention to the empirical study of law and legal institutions in law schools, both within and outside the United States. In the early years of its existence, the L\&S movement - as mentioned, another important site for the empirical study of law and legal institutions also had its centre of gravity inside the law schools. But over time, it shifted towards the social sciences. This article discusses how that happened and goes on to explain how the $L \& S$ movement became ever more diverse in terms of substance, theory and methods. As such, it deepens scholarly understanding of the L\&S movement and thereby strengthens debates about the relationship between the ELR movement and the L\&S movement.

Apparently, there are substantive differences and tensions between the ELR movement and the L\&S movement, but these cannot be generalised. For this, the relationship between both differs too much between contexts and is too dynamic.

In closing, it can be stated that the first two contributions of this special issue relate to the boundary between law and empiricism and the bridging thereof. The third contribution to this special issue zooms in on the relationship between legal scholarship and the empirical study of the law, while the last contribution addresses the relationship between the ELR movement and other research traditions that empirically study law. As such, this special issue on 'Empirical Legal Research: Fad, Feud or Fellowship?' analyses the differences and tensions between the more recent ELR movement, the L\&S movement and traditional legal scholarship. Thereby, it intends to provide a better understanding of the academically debated field of legal scholarship. 